\title{
Correction to: An update and reassessment of fern and lycophyte diversity data in the Japanese Archipelago
}

\author{
Atsushi Ebihara ${ }^{1} \mathbb{D}$. Joel H. Nitta ${ }^{2}$
}

Published online: 18 October 2019

(c) The Author(s) 2019

Correction to: Journal of Plant Research https://doi.org/10.1007/s10265-019-01137-3

In the original publication of this article, the affiliation of one of the authors was listed incorrectly as "Smithsonian Institute". The correct affiliation is "Smithsonian Institution".

Open Access This article is distributed under the terms of the Creative Commons Attribution 4.0 International License (http://creativeco mmons.org/licenses/by/4.0/), which permits unrestricted use, distribution, and reproduction in any medium, provided you give appropriate credit to the original author(s) and the source, provide a link to the Creative Commons license, and indicate if changes were made.

The original article can be found online at https://doi.org/10.1007/ s10265-019-01137-3.

Atsushi Ebihara

ebihara@kahaku.go.jp

1 Department of Botany, National Museum of Nature and Science, 4-1-1 Amakubo, Tsukuba, Ibaraki 305-0005, Japan

2 Department of Botany, National Museum of Natural History, Smithsonian Institution, Washington, DC 20013, USA 